\title{
Ecotoxicity assessment of dicationic versus monocationic ionic liquids as a more environmentally friendly alternative
}

\author{
M. G. Montalbánª, G. Víllora ${ }^{a *}$, P. Licence ${ }^{\mathrm{b}}$ \\ ${ }^{a}$ Department of Chemical Engineering, Faculty of Chemistry, Regional Campus of International \\ Excellence "Campus Mare Nostrum", University of Murcia, P.O. Box 4021, Campus of \\ Espinardo, E-30071, Murcia, Spain.
}

${ }^{\mathrm{b}}$ School of Chemistry, The University of Nottingham, Nottingham, NG7 2RD, UK.

*Corresponding author. E-mail: gvillora@um.es. Telephone: +34 868887363.

\section{ABSTRACT}

One of the reasons why ionic liquids have received growing interest from researchers is their environmentally interesting characteristics, such as their negligible vapour pressure and their good chemical and thermal properties. In particular, dicationic ionic liquids whose thermal and electrochemical stability is higher than that of monocationic ionic liquids have begun to gain attention during recent years. In this work, monocationic and dicationic ionic liquids were synthesized, characterized and tested for their toxicity, which was assessed using the luminescent bacterium Vibrio fischeri. The results revealed that the toxicity of the ionic liquids mainly depends on the head groups and linkage chain length of their cationic structure. Introduction of a new cationic head decreased the $\mathrm{EC}_{50}$ (concentration which leads to $50 \%$ reduction in bioluminescence of the bacteria) of the ionic liquids. The results present a promising picture of dicationic ionic liquids as alternatives with lower environmental impact than their monocationic counterparts and underline the significance of designing particular structures for ionic liquids.

Keywords: Monocationic; dicationic; ionic liquid; toxicity; Microtox ${ }^{\circledR}$ test; Vibrio fischeri. 


\section{INTRODUCTION}

Ionic liquids (ILs) are organic salts which are liquids at or near ambient conditions $\left(\mathrm{T}<100^{\circ} \mathrm{C}\right)$. ILs have gained much attention as alternative solvents during recent years due to their rather unique combination of physical and chemical properties, which include negligible vapour pressure, non-flammability, wide liquid state temperature range, high thermal and chemical stability and high ionic conductivity (Lee and Lin, 2014). Moreover, the properties of ILs can be tuned by adjusting the structures of their anion and cation, or both, leading ILs to become known as "designer solvents" (Viswanathan et al., 2006). In this way, it is possible to control several physical properties, such as hydrophobicity, viscosity, density, solubility and their biodegradability and toxicological behaviour (Ventura et al., 2012). Because of these properties, monocationic ILs can be used in a wide variety of applications in different inter-disciplinary research areas, such as in the field of chemical engineering, organic synthesis, separation process, material science, catalysis, biocatalysis, green chemistry, sensoristics, medicine, electrochemistry, electronic devices (Galinski et al., 2006; Hough et al., 2007; Kogelnig et al., 2010; Kore et al., 2013; Wasserscheid and Welton, 2008) and supported liquid membranes (Víllora, 2013).

Geminal (symmetrical) dicationic ILs are generally composed of two distal cationic head groups linked by some form of linking fragment, which may be composed of simple alkyl chain, or more functional in nature. These compounds are especially interesting because they generally possess higher thermal and electrochemical stability, making them more suitable than monocationic ILs for use in high-temperature applications (Steudte et al., 2014). In this context, the suitability of dicationic ILs as reaction media has been studied when high temperatures are necessary (Han and Armstrong, 2005). They have great potential to be used as solvents for high temperature uses, surfactants, lubricants, nanoparticle coating, gas chromatography stationary phases, separation media and catalyst for esterification and transesterification reactions (Wei-Li et al., 2014; Anderson et al., 2005). 
Asymmetrical dicationic ILs are another type of dicationic ILs which consist of different head groups of cation which are also attached via a linking fragment such as an alkyl chain. These asymmetrical ILs can be said to have dual functionality as they have two different head groups (Masri et al., 2016). Asymmetrical dicationic ILs based on both imidazolium and aliphatic ammonium have been synthesized as potential electrolyte additives applied to lithium secondary batteries (Zhang et al., 2008).

On the other hand, heteroanionic dicationic ILs can be symmetrical or asymmetrical (head groups), but they have one dication with two different anions. Currently, dicationic ILs are extensively investigated as separation material (supported liquid membrane technology) and catalyst candidates (hydrolysis, biodiesel production, esterification of carboxylic acid...) (Masri et al., 2016).

Although ILs should not contribute to atmospheric pollution due to their non-volatility (Pham et al., 2010), they can be easily soluble in water and therefore could be toxic to aquatic organisms (Freire et al., 2009) in cases of accidental release or at the end of their life cycle. For this reason, the environmental behaviour and toxicological effects of ILs need to be evaluated. However, more studies related to the ecotoxicological risk profiles of ILs are required because of the huge number of ILs that can be synthesized (Ventura et al., 2011; Lee and Lee, 2009). During the past few years, some publications have studied IL toxicity using different aquatic organisms such as bacteria (especially, Vibrio fischeri) (Montalbán et al., 2016; Samorì et al., 2007; Pinto et al., 2012, García et al., 2005; Docherty and Kulpa, Jr., 2005; Romero et al., 2008; Stolte et al., 2007; Ventura et al., 2011, 2012, 2014; Luis et al., 2007), green algae (e.g. Pseudokirchneriella subcapitata) (Pretti et al., 2011; Pham et al., 2008), aquatic plants (e.g. duckweed Lemna minor) (Stolte et al., 2007; Larson et al., 2008; Zhang et al., 2013), invertebrates (mainly the freshwater crustacean Daphnia magna and Artemia Salina) (Pretti et al., 2011; Wells and Coombe, 2006; Steudte et al., 2014; Gouveia et al., 2014; Vraneš et al., 2016) or vertebrates like fish (the zebrafish Danio rerio) (Pretti et al., 2006, 2011) or frogs (Rana nigromaculata) (Li et al., 2009). In these studies, ILs show a varying hazard potential, 
depending on their individual chemical structure and morphology. Regardless of the studied test system, the strongest effect on IL toxicity seems to be their lipophilicity (Steudte et al., 2014). However, despite the increasing number of studies which evaluate IL aquatic toxicity, the information available is still limited, especially information related to dicationic ILs.

Several published works have attempted to predict the aquatic toxicity of ILs by Quantitative Structure-Activity Relationships (QSAR) methods (Luis et al., 2007, 2010; Lacrămă et al., 2007; Ismail Hossain et al., 2011; Couling et al., 2006; Bruzzone et al., 2011) which are mathematical models mainly based on the anion, the cation core and the length of the alkyl chain of the cation of the IL. Nevertheless, this kind of models is not sufficiently well developed to be applied to more complex or functional structures including relatively simple dicationic ILs. For this reason, more experimental data concerning the toxicity of dicationic ILs are required for incorporation in the respective databases, which will help predict their toxicity.

According to Ventura et al. (2011), one of the most widely used toxicological tests is the Microtox ${ }^{\circledR}$ Acute Toxicity Test, which uses the gram negative marine bacterium Vibrio fischeri (formerly known as Photobacterium phosphoreum). In 2007, Vibrio fischeri was renamed to Aliivibrio fischeri (Urbanczyk et al., 2007). This test is one of the most commonly used bioassay tests due to the intense and stable light emission of these bacteria and because it is highly sensitive to different compounds (Fuentes et al., 2006), and has been used for more than two decades in a large number of studies to determine the toxicity of conventional organic compounds toxicity for more than two decades (Kaiser and Palabrica, 1991). In fact, this method constitutes a standard (eco) toxicological inhibition assay in Europe (DIN EN ISO 11348) ("ISO 11348-3. Water quality. Determination of the inhibitory effect of water samples on the light emission of Vibrio fischeri (Luminescent bacteria test). Part 3: Method using freezedried bacteria," 2007), which determines the toxicity of a substance toward Vibrio fischeri by measuring the diminution in their light output. This decrease in Vibrio fischeri light emission is due to a reduction in enzymatic activity, so that any luminiscence is directly proportional to the metabolic activity of the bacterial population (Parvez et al., 2006). 
The main goal of this work was to measure the aquatic toxicity of a set of twenty-six imidazolium, pyrrolidinium and pyridinium-based ILs (9 monocationic and 17 dicationic) (see Table 1 in Montalbán et al., 2017) using the Vibrio fischeri inhibition test as the effective nominal $\mathrm{EC}_{50}$ concentration (concentration necessary to decrease $50 \%$ of luminescence produced by the bacteria population). To date, the synthesis of some of these compounds has not been reported and hence no report in the literature has studied the toxicity of the most of these ILs (22 out of 26) towards Vibrio fischeri. The results represent an accurate study of the influence of the composition and structure on ILs toxicities.

\section{MATERIALS AND METHODS}

115

\subsection{Test Chemicals}

1-methylimidazole (>99\%), 1-methylpyrrolidine (>98\%), pyridine (>99\%), 1-bromooctane (>99\%), 1,2-dibromoethane (>98\%), 1,3-dibromopropane (>99\%), 1,4-dibromobutane (>99\%), 1,6-dibromohexane (>96\%), 1,8-dibromooctane (>98\%), 1,12-dibromododecane (98>\%), lithium bis(trifluoromethane)sulfonylimide (99.95>\%) sodium hexafluoroantimonate (V) (technical grade), acetonitrile, ethyl acetate, dichloromethane and methanol were purchased from Sigma Aldrich (Steinheim, Germany). All chemical products were used without additional purification.

\subsection{Synthesis and characterization}

125 All ILs investigated herein were prepared in the laboratories of the University of Nottingham. A full description of each chemical synthesis is provided in Montalbán et al., 2017. Full characterization data of all the compounds, including ${ }^{1} \mathrm{H}$ NMR, ${ }^{13} \mathrm{C}$ NMR and ${ }^{19} \mathrm{~F}$ NMR spectroscopy and mass spectrometry (MS), are also provided in Montalbán et al., 2017. Melting point temperature or thermal decomposition temperature of the solid ILs at room temperature was measured and included in Montalbán et al., 2017 (see Table 2). 


\subsection{Toxicity tests}

135

The Microtox ${ }^{\circledR}$ Toxicity Test evaluates any inhibition in luminescence of the marine Gramnegative bacterium Vibrio fischeri. This bacterium was purchased in lyophilized form from Modern Water and activated by rehydration with a restorative solution of MilliQ water. A control sample of the bacterial suspension without the test substance was included along with the sample. Both, standard and samples were used in $2 \% \mathrm{NaCl}$ to adjust the osmotic pressure. A Microtox ${ }^{\circledR}$ M500 Analyzer (Azur Environmental) was used to measure the light emission of the bacterium in contact with the samples. In this test, a range of diluted aqueous solutions (from 5.625 to $45.000 \%$ ) of each IL was used. A concentration of $100 \%$ corresponds to a known concentration of an IL stock solution. After 15 minutes of exposure to the IL solution, whose concentration depends on the IL, the light output of the luminescent bacterium was measured and compared with the light output of a blank control sample. The toxicity was evaluated and a $50 \%$ reduction in luminescence was computed. The toxicity values reported in the text and tables are expressed as $\log \mathrm{EC}_{50}(\mu \mathrm{M})$, representing the toxicity value measured 15 min after Vibrio fischeri comes in contact with an IL. The measurement was taken at least three times for most ILs.

150

\section{RESULTS AND DISCUSSION}

The above mentioned mono- and dicationic ILs were synthesized and their ecotoxicity towards the luminescent marine bacterium Vibrio fischeri was evaluated. The yield of the synthesis reactions varied between $35.4 \%$ and $99.9 \%$.

Tables 1 and 2 show the experimental results of the $\mathrm{EC}_{50}$ for monocationic and dicationic ILs, respectively. Table 1 also includes the $\mathrm{EC}_{50}$ values found in the literature and estimated by a QSAR method. There are no data available for dicationic ILs (Table 2). Table S1 shows the $\mathrm{EC}_{50}$ values of common volatile organic compounds (VOCs) collected from the literature. Figure 1 depicts the $\mathrm{EC}_{50}$ values collated in Tables 1, 2 and $\mathrm{S} 1$ for comparison. 
To obtain less toxic ILs, several structural changes affecting the cation core (in mono- and dicationic ILs), the central alkyl chain length (only in dicationic ILs) and the anion (only in monocationic ILs) were introduced. The influence of these parameters on ILs toxicity was analyzed. In an attempt to increase the readability of this study, the main results will be discussed in three sections: monocationic ILs, dicationic ILs and mono- versus dicationic ILs.

Table 1. $\log \mathrm{EC}_{50}$ values for monocationic ILs tested in each trial after $15 \mathrm{~min}$ of exposure of the luminescent bacterium Vibrio fischeri, with respective 95\% confidence limits (in brackets) and $\log \mathrm{EC}_{50}$ mean values. $\log \mathrm{EC}_{50}$ values found in the literature and $\log \mathrm{EC}_{50}$ obtained using a group contribution method QSAR (Luis et al., 2010) are also shown. Toxicity is expressed as $\log \mathrm{EC}_{50}(\mu \mathrm{M})$.

\begin{tabular}{|c|c|c|c|c|}
\hline Ionic liquid & $\begin{array}{l}\text { Log EC } \mathbf{E}_{50} \text {, this work } \\
\text { (lower limit, upper limit) }\end{array}$ & $\begin{array}{l}\text { Log EC } \mathbf{E}_{50} \\
\text { this work } \\
\text { (average) }\end{array}$ & $\begin{array}{l}\text { Log } \mathbf{E C}_{50} \\
\text { from literature }\end{array}$ & $\begin{array}{l}\log \text { EC }_{50} \\
\text { from QSAR }\end{array}$ \\
\hline \multirow{3}{*}{$\mathrm{C}_{8}(\mathrm{MIm}) \mathrm{Br}$} & $0.75(0.45,1.05)$ & \multirow{3}{*}{0.71} & \multirow{3}{*}{$0.63^{b} ; 2.27^{c}$} & \multirow{3}{*}{1.17} \\
\hline & $0.78(0.75,0.80)$ & & & \\
\hline & $0.60(0.30,0.89)$ & & & \\
\hline \multirow{3}{*}{$\mathrm{C}_{8}(\mathrm{MIm}) \mathrm{NTf}_{2}$} & $0.99(0.96,1.02)$ & \multirow{3}{*}{0.95} & \multirow{3}{*}{-} & \multirow{3}{*}{0.76} \\
\hline & $0.93(0.87,1.00)$ & & & \\
\hline & $0.92(0.89,0.96)$ & & & \\
\hline \multirow{3}{*}{$\mathrm{C}_{8}(\mathrm{MIm}) \mathrm{SbF}_{6}$} & $0.96(0.93,0.99)$ & \multirow{3}{*}{0.85} & \multirow{3}{*}{-} & \multirow{3}{*}{-} \\
\hline & $0.83(0.63,1.02)$ & & & \\
\hline & $0.78(0.61,1.82)$ & & & \\
\hline \multirow{3}{*}{$\mathrm{C}_{8}(\mathrm{Pyr}) \mathrm{Br}$} & $1.24(1.01,1.47)$ & \multirow{3}{*}{1.27} & \multirow{3}{*}{$1.89^{c}$} & \multirow{3}{*}{0.95} \\
\hline & $1.27(1.09,1.46)$ & & & \\
\hline & $1.30(1.10,1.50)$ & & & \\
\hline \multirow{3}{*}{$\mathrm{C}_{8}(\mathrm{Pyr}) \mathrm{NTf}_{2}$} & $1.47(1.38,1.57)$ & \multirow{3}{*}{1.51} & \multirow{3}{*}{-} & \multirow{3}{*}{-} \\
\hline & $1.48(1.42,1.54)$ & & & \\
\hline & $1.59(1.49,1.69)$ & & & \\
\hline \multirow{3}{*}{$\mathrm{C}_{8}(\mathrm{Pyr}) \mathrm{SbF}_{6}$} & $1.14(0.99,1.29)$ & \multirow{3}{*}{1.13} & \multirow{3}{*}{-} & \multirow{3}{*}{-} \\
\hline & $1.07(0.99,1.16)$ & & & \\
\hline & $1.18(1.14,1.22)$ & & & \\
\hline \multirow{3}{*}{$\mathrm{C}_{8}$ (MPyrr) $\mathrm{Br}$} & $1.53(1.46,1.60)$ & \multirow{3}{*}{1.66} & \multirow{3}{*}{$2.26^{c}$} & \multirow{3}{*}{1.96} \\
\hline & $1.72(1.60,1.84)$ & & & \\
\hline & $1.74(1.59,1.87)$ & & & \\
\hline \multirow{3}{*}{$\mathrm{C}_{8}$ (MPyrr) $\mathrm{NTf}_{2}$} & $1.48(1.45,1.50)$ & \multirow{3}{*}{1.53} & \multirow{3}{*}{$1.58^{c}$} & \multirow{3}{*}{0.34} \\
\hline & $1.54(1.37,1.71)$ & & & \\
\hline & $1.58(1.57,1.60)$ & & & \\
\hline & $1.71(1.13,2.30)$ & & & \\
\hline $\mathrm{C}_{8}$ (MPyrr) $\mathrm{SbF}_{6}$ & $1.69(0.75,2.63)$ & & & \\
\hline $\mathrm{C}_{8}$ (MPyrr) SbF6 & $1.67(1.00,2.34)$ & 1.69 & - & - \\
\hline & $1.69(0.73,2.65)$ & & & \\
\hline
\end{tabular}


Table 2. $\log \mathrm{EC}_{50}(\mu \mathrm{M})$ values for dicationic ILs tested in each trial after $15 \mathrm{~min}$ of exposure of 175 the luminescent bacterium Vibrio fischeri, with respective 95\% confidence limits (in brackets).

\begin{tabular}{|c|c|c|}
\hline Ionic liquid & $\begin{array}{l}\log \mathbf{E C}_{50}(\boldsymbol{\mu M}) \text {, this work } \\
\text { (lower limit, upper limit) }\end{array}$ & $\begin{array}{l}\log \mathbf{E C}_{50}(\mu \mathrm{M}) \text {, } \\
\text { this work (average) }\end{array}$ \\
\hline $\mathrm{C}_{2}(\mathrm{MIm})_{2} \mathrm{Br}_{2}$ & $5.35(5.05,5.64)$ & 5.35 \\
\hline \multirow{3}{*}{$\mathrm{C}_{3}(\mathrm{MIm})_{2} \mathrm{Br}_{2}$} & $5.40(5.24,5.56)$ & \multirow{3}{*}{5.37} \\
\hline & $5.30(5.23,5.37)$ & \\
\hline & $5.41(5.05,5.77)$ & \\
\hline \multirow{3}{*}{$\mathrm{C}_{4}(\mathrm{MIm})_{2} \mathrm{Br}_{2}$} & $5.02(4.67,5.36)$ & \multirow{3}{*}{5.00} \\
\hline & $5.06(4.87,5.25)$ & \\
\hline & $4.92(4.53,5.31)$ & \\
\hline \multirow{3}{*}{$\mathrm{C}_{6}(\mathrm{MIm})_{2} \mathrm{Br}_{2}$} & $4.54(4.09,4.99)$ & \multirow{3}{*}{4.56} \\
\hline & $4.59(4.14,5.05)$ & \\
\hline & $4.56(4.11,5.01)$ & \\
\hline \multirow{3}{*}{$\mathrm{C}_{8}(\mathrm{MIm})_{2} \mathrm{Br}_{2}$} & $2.33(2.20,2.45)$ & \multirow{3}{*}{2.34} \\
\hline & $2.34(2.18,2.49)$ & \\
\hline & $2.35(2.21,2.50)$ & \\
\hline \multirow{4}{*}{$\mathrm{C}_{3}(\mathrm{MPyrr})_{2} \mathrm{Br}_{2}$} & $5.18(5.14,5.23)$ & \multirow{4}{*}{5.07} \\
\hline & $4.89(4.61,5.18)$ & \\
\hline & $5.13(4.99,5.28)$ & \\
\hline & $5.06(4.99,5.13)$ & \\
\hline \multirow{4}{*}{$\mathrm{C}_{4}(\mathrm{MPyrr})_{2} \mathrm{Br}_{2}$} & $4.26(3.97,4.55)$ & \multirow{4}{*}{4.31} \\
\hline & $4.28(3.88,4.68)$ & \\
\hline & $4.36(4.01,4.70)$ & \\
\hline & $4.33(4.01,4.65)$ & \\
\hline \multirow{3}{*}{$\mathrm{C}_{6}(\mathrm{MPyrr})_{2} \mathrm{Br}_{2}$} & $4.17(4.10,4.23)$ & \multirow{3}{*}{4.08} \\
\hline & $4.22(4.04,4.40)$ & \\
\hline & $3.86(3.69,4.04)$ & \\
\hline \multirow{6}{*}{$\mathrm{C}_{8}(\mathrm{MPyrr})_{2} \mathrm{Br}_{2}$} & $3.64(2.63,4.64)$ & \multirow{6}{*}{3.77} \\
\hline & $3.69(3.48,3.90)$ & \\
\hline & $4.00(3.78,4.23)$ & \\
\hline & $3.82(3.49,4.14)$ & \\
\hline & $3.51(3.22,3.79)$ & \\
\hline & $3.95(3.77,4.13)$ & \\
\hline \multirow{2}{*}{$\mathrm{C}_{2}(\mathrm{Pyr})_{2} \mathrm{Br}_{2}$} & $5.37(5.31,5.42)$ & \multirow{2}{*}{5.40} \\
\hline & $5.42(5.25,5.60)$ & \\
\hline \multirow{3}{*}{$\mathrm{C}_{3}(\mathrm{Pyr})_{2} \mathrm{Br}_{2}$} & $4.59(4.48,4.71)$ & \\
\hline & $4.60(4.49,4.70)$ & 4.56 \\
\hline & $4.48(4.46,4.50)$ & \\
\hline & $4.93(4.81,5.05)$ & \\
\hline $\mathrm{C}_{4}(\mathrm{Pyr})_{2} \mathrm{Br}_{2}$ & $5.15(5.04,5.26)$ & 5.04 \\
\hline & $5.03(4.90,5.17)$ & \\
\hline & $5.11(4.76,5.46)$ & \\
\hline $\mathrm{C}_{6}(\mathrm{Pyr})_{2} \mathrm{Br}_{2}$ & $5.17(4.94,5.40)$ & 518 \\
\hline & $5.31(4.57,6.05)$ & 5.18 \\
\hline & $5.13(4.90,5.36)$ & \\
\hline & $4.19(3.32,5.06)$ & \\
\hline & $4.64(4.58,4.71)$ & \\
\hline $\mathrm{C}_{8}(\mathrm{Pyr})_{2} \mathrm{Br}_{2}$ & $4.39(2.93,5.85)$ & 4.52 \\
\hline & $4.62(4.55,4.68)$ & \\
\hline & $4.77(4.76,4.82)$ & \\
\hline & $2.07(2.04,2.11)$ & \\
\hline $\mathrm{C}_{12}(\mathrm{Pyr})_{2} \mathrm{Br}_{2}$ & $2.04(2.01,2.07)$ & 2.07 \\
\hline & $2.09(2.06,2.13)$ & \\
\hline & $5.18(4.77,5.59)$ & \\
\hline & $5.24(5.04,5.44)$ & \\
\hline $\mathrm{C}_{3}(\mathrm{Pyr})(\mathrm{MIm}) \mathrm{Br}_{2}$ & $5.31(5.28,5.34)$ & 5.23 \\
\hline & $5.19(5.04,5.34)$ & \\
\hline & $4.54(4.51,4.58)$ & \\
\hline $\mathrm{C}_{3}$ (Pyr) (MPyrr) $\mathrm{Br}_{2}$ & $4.59(4.57,4.81)$ & 4.55 \\
\hline & $4.52(4.19,4.85)$ & \\
\hline
\end{tabular}




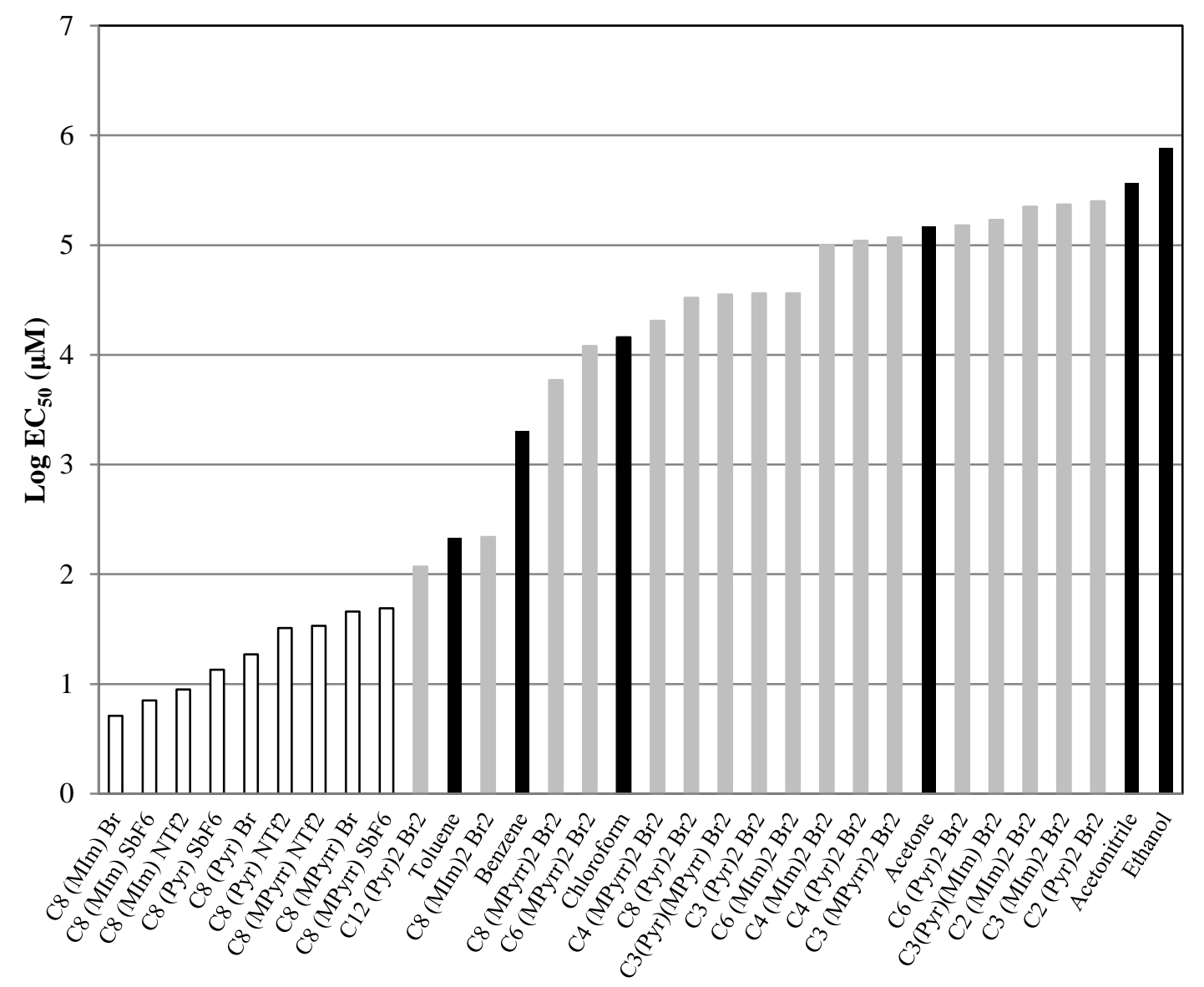

Figure 1. Comparison between $\log \mathrm{EC}_{50}$ values of ILs (white and grey rectangles, monocationic and dicationic ILs, respectively) and COVs (black rectangles).

\subsection{Monocationic ILs}

The toxicity of monocationic ILs towards Vibrio fischeri has been widely screened in the present work. The $\log \mathrm{EC}_{50}$ values of monocationic ILs (Table 1) reflect influence of two structural features on the bacterial toxicity: the influence of the cation core in ILs with the same anion and the influence of the anion in ILs with the same cation.

A variety of toxicology studies (Matzke et al., 2007, 2008) have correlated the lipophilicity of ion-pairs constituent of the ILs with their biological activities, suggesting that the disruption of the plasma membrane plays the major role in ILs toxicity. Moreover, several ILs act as 
surfactants which are generally highly disruptive to membranes (Gal et al., 2012). For this reason, the increasing emphasis on the characterization of membrane binding and disruption induced by ILs as putative critical biological determinants is based upon the notion that the lipid bilayer is naturally the first cellular constituent encountered by the ILs. Furthermore, the plasma membrane is a well-known target for varied biological substances, both water-soluble as well as amphiphilic (Bechinger, 2010).

Analysis of the $\mathrm{C}_{8}(\mathrm{MIm})^{+}, \mathrm{C}_{8}(\mathrm{Pyr})^{+}$and $\mathrm{C}_{8}(\mathrm{MPyrr})^{+}$derivatives showed that, for the same anion, the order in toxicity was $\mathrm{C}_{8}(\mathrm{MIm})^{+}>\mathrm{C}_{8}(\mathrm{Pyr})^{+}>\mathrm{C}_{8}(\mathrm{MPyrr})^{+}$. These results agree with those obtained by Docherty and Kulpa (Docherty and Kulpa, Jr., 2005). This fact could be explained on the basis of the cation structure. The imidazolium and pyridinium are both flat, in the imidazolium the positive charge is distributed across two nitrogens and if one considers separated charges or charge distribution the net positive charge on each atom is very different to the pyridinium analogue where the polarisation of the head group is greater, i.e. its delta positive is much more focused. In the pyrrolidinium, the magnitude of the positive charge is comparable with the pyridinium, but the nitrogen is tetrahedral and the carbon substituents are somewhat more puckered, the nitrogen is "hidden" inside an envelope of carbon such that the positive charge is not as accessible (Blundell and Licence, 2014a, 2014b). Therefore, due to the planarity of the aromatic cations, such as imidazolium or pyridinium, monocationic ILs based on these cations presumably possess lower steric hindrance which could increase the interactions with the membrane lipid bilayer and hence increase their toxicity. The results of the $\mathrm{EC}_{50}$ tell us that symmetry of the head group is dominant on the magnitude of the positive charge on each atom. Gal et al. (2012) obtained results particularly significant from a structural standpoint. They point that the head group structure and orientation are key factors that determine membrane interactions and concurrent toxicity. While an increase in the cationic side chain length of an IL might be directly related to an increase in membrane activity, the orientation of head cationic group emerges as an structural and biological element that has to be also considered in ILs toxicity. 
From Table 1, it can be observed that the $\log \mathrm{EC}_{50}$ values for a given anion series are very similar and no general trend for the anion constituent of the monocationic ILs studied could be established concerning toxicity towards Vibrio fischeri. Many authors have suggested that the cation has a much stronger effect on ionic liquid toxicity than the anion (Montalbán et al., 2016; Docherty and Kulpa, Jr., 2005; Romero et al., 2008; Couling et al., 2006; Gal et al., 2012; Stolte et al., 2007; Matzke et al., 2008; Evans, 2006). This is quite expected because most cellular membranes exhibit negative charge and therefore would be affected much more significantly by the cationic components of ILs, although membrane interactions of ILs are in fact dictated by more subtle mechanisms (Gal et al., 2012). The toxicity of ILs has been correlated with increasing alkyl chain length of the cationic constituent, proposing that the alkyl chains are inserted through the polar head group region of the membrane bilayer, and consequently induce membrane damage and cell death. In fact, in our case, the long alkyl chain (octyl) on the cation has a stronger effect on toxicity than the effect of the anion.

\subsection{Dicationic ILs}

The $\log \mathrm{EC}_{50}$ values of dicationic ILs depicted in Table 2 allow to analyze the influence of three different structural features on the toxicity of the ILs towards the marine bacteria: i) the effect of the cation core nature, ii) the charge carrier symmetry, flat or tetrahedral, with the same anion (bromide) and iii) the influence of the alkyl linkage chain length in ILs with the same cation core.

In order to assess the influence of the cation core on the toxicity towards Vibrio fischeri, two families of dicationic ILs were synthesized: fifteen symmetrical (imidazolium, pyridinium and pyrrolidinium-based ILs) and two asymmetrical (pyridinium-imidazolium and pyridiniumpyrrolidinium ILs).

As it can be seen in Table 2 and Figure 2, the effect of the cation core over the Vibrio fischeri toxicity depends on the alkyl chain length of the cation. The following order was obtained for the toxicity of dicationic ILs with alkyl linkage chains comprising three atoms of carbon: $\mathrm{C}_{3}(\mathrm{Pyr})_{2} \mathrm{Br}_{2}\left(\log \mathrm{EC}_{50}=4.56\right)>\mathrm{C}_{3}(\mathrm{mPyrr})_{2} \mathrm{Br}_{2}\left(\log \mathrm{EC}_{50}=5.07\right)>\mathrm{C}_{3}(\mathrm{MIm})_{2} \mathrm{Br}_{2}\left(\log \mathrm{EC}_{50}=5.37\right)$, 
while the opposite order for the analogous ILs with eight carbon atoms: $\mathrm{C}_{8}(\mathrm{MIm})_{2} \mathrm{Br}_{2}(\log$ $\left.\mathrm{EC}_{50}=2.34\right)>\mathrm{C}_{8}(\mathrm{MPyrr})_{2} \mathrm{Br}_{2}\left(\log \mathrm{EC}_{50}=3.77\right)>\mathrm{C}_{8}(\mathrm{Pyr})_{2} \mathrm{Br}_{2}\left(\log \mathrm{EC}_{50}=4.52\right)$. A similar conclusion was previously suggested by Docherty and Kulpa, Jr. (2005) for monocationic ILs, who found that imidazolium and pyridinium toxicities could not be directly compared because, according to their results, $\mathrm{C}_{4}(\mathrm{MIm}) \mathrm{Br}$ was significantly less toxic than $\mathrm{C}_{4}(\mathrm{MPyr}) \mathrm{Br}$ but $\mathrm{C}_{6}(\mathrm{MIm}) \mathrm{Br}$ was more toxic than $\mathrm{C}_{6}(\mathrm{MPyr}) \mathrm{Br}$ and, in the case of eight atoms of carbon, $\mathrm{C}_{8}(\mathrm{MIm}) \mathrm{Br}$ and $\mathrm{C}_{8}(\mathrm{MPyr}) \mathrm{Br}$ had similar toxicities.

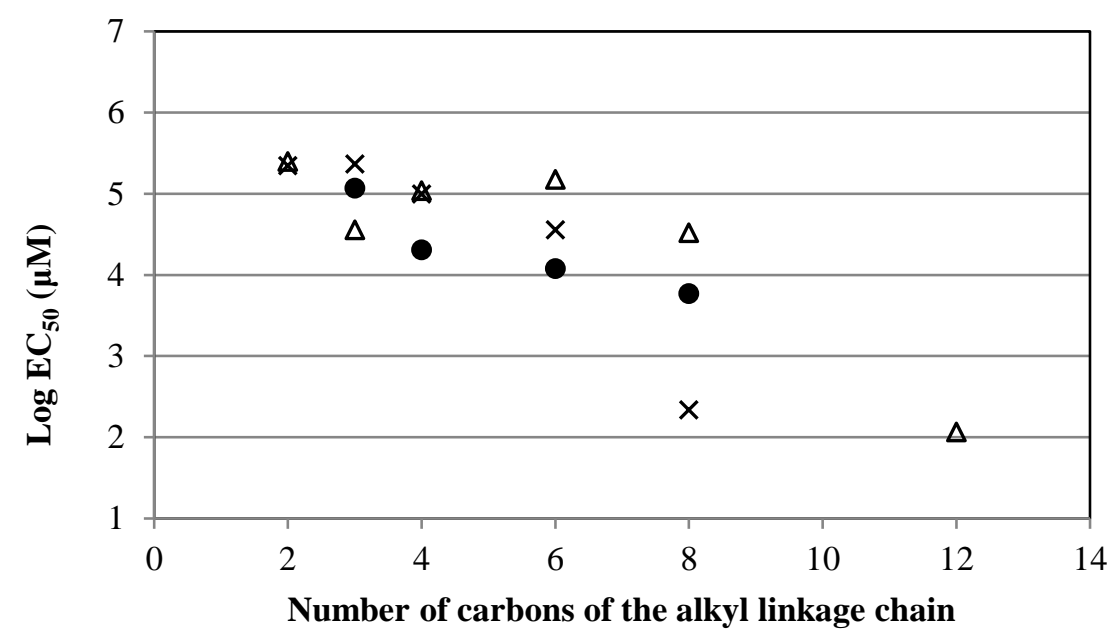

Figure 2. Effect of the number of carbons of the alkyl linkage chain on the aquatic toxicity (Log $\left.\mathrm{EC}_{50}\right)$ of dicationic ILs with different cation cores; $\times$ methylimidazolium, methylpyrrolidinium and $\Delta$ pyridinium.

Comparing symmetrical and asymmetrical dicationic ILs, the following toxicity order was established (see Table 2): $\mathrm{C}_{3}(\mathrm{Pyr})_{2} \mathrm{Br}_{2}\left(\log \mathrm{EC}_{50}=4.56\right)>\mathrm{C}_{3}(\mathrm{Pyr})(\mathrm{MIm}) \mathrm{Br}_{2}\left(\log \mathrm{EC}_{50}=5.23\right)>$ $\mathrm{C}_{3}(\mathrm{MIm})_{2} \mathrm{Br}_{2}\left(\log \mathrm{EC}_{50}=5.37\right)$ and $\mathrm{C}_{3}(\mathrm{Pyr})_{2} \mathrm{Br}_{2}\left(\log \mathrm{EC}_{50}=4.56\right) \approx \mathrm{C}_{3}(\mathrm{Pyr})(\mathrm{MPyrr}) \mathrm{Br}_{2}(\log$ $\left.\mathrm{EC}_{50}=4.55\right)>\mathrm{C}_{3}(\mathrm{MPyrr})_{2} \mathrm{Br}_{2}\left(\log \mathrm{EC}_{50}=5.07\right)$. This strongly suggests that, for short alkyl linkage chains, pyridinium-based ILs are more toxic than imidazolium and pyrrolinium-based ones and is in close agreement with Docherty and Kulpa, Jr. (2005).

The effect of the alkyl linkage chain length on the toxicity of dicationic ILs towards the luminescent bacteria was investigated by comparing dicationic ILs containing the same cation 
core but different central chain. In this specific case, we examined the following series: from $\mathrm{C}_{2}(\mathrm{MIm})_{2} \mathrm{Br}_{2}$ to $\mathrm{C}_{8}(\mathrm{MIm})_{2} \mathrm{Br}_{2}$, from $\mathrm{C}_{3}(\mathrm{MPyrr})_{2} \mathrm{Br}_{2}$ to $\mathrm{C}_{8}(\mathrm{MPyrr})_{2} \mathrm{Br}_{2}$ and from $\mathrm{C}_{2}(\mathrm{Pyr})_{2} \mathrm{Br}_{2}$ to $\mathrm{C}_{12}(\mathrm{Pyr})_{2} \mathrm{Br}_{2}$ (Table 2 and Figure 2). The ecotoxicity of the ILs can be ranked as follows: $\mathrm{C}_{8}(\log$ $\left.\mathrm{EC}_{50}=2.34\right)>\mathrm{C}_{6}\left(\log \mathrm{EC}_{50}=4.56\right)>\mathrm{C}_{4}\left(\log \mathrm{EC}_{50}=5.00\right)>\mathrm{C}_{3}\left(\log \mathrm{EC}_{50}=5.37\right) \approx \mathrm{C}_{2}(\log$ $\left.\mathrm{EC}_{50}=5.35\right)$ for the imidazolium-based ILs, $\mathrm{C}_{8}\left(\log \mathrm{EC}_{50}=3.77\right)>\mathrm{C}_{6}\left(\log \mathrm{EC}_{50}=4.08\right)>\mathrm{C}_{4}(\log$ $\left.\mathrm{EC}_{50}=4.31\right)>\mathrm{C}_{3}\left(\log \mathrm{EC}_{50}=5.07\right)$ for the pyrrolidinium-based ILs and, finally, $\mathrm{C}_{12}(\log$ $\left.\mathrm{EC}_{50}=2.07\right)>\mathrm{C}_{8}\left(\log \mathrm{EC}_{50}=4.52\right) \approx \mathrm{C}_{3}\left(\log \mathrm{EC}_{50}=4.56\right)>\mathrm{C}_{6}\left(\log \mathrm{EC}_{50}=5.18\right) \approx \mathrm{C}_{4}(\log$ $\left.\mathrm{EC}_{50}=5.04\right)>\mathrm{C}_{2}\left(\log \mathrm{EC}_{50}=5.40\right)$ for the pyridinium-based ILs. The increase in toxicity (and lower $\mathrm{EC}_{50}$ values) when the alkyl linkage chain increases is due to the higher hydrophobicity and cell permeability.

According to these results, for the families of imidazolium and pyrrolidinium-based ILs tested in this work, toxicity towards Vibrio fischeri increases with the length of the alkyl linkage chain. However, in case of the pyridinium-based ILs studied, although the same general trend existed, the results were not so clear as for the other two families of ILs. Although, the results available in the literature related to dicationic ILs toxicity are scarce, their tendencies generally agree with our experimental data (Gindri et al., 2014; e Silva et al., 2014; Steudte et al., 2014). For instance, Steudte et al. (2014) found that acetylcholinesterase inhibition and toxicity towards Daphnia magna diminished with short alkyl linkage chains in some of the imidazolium-based dicationic ILs tested in this work. In addition, the results of e Silva et al. (2014) showed the same trend for Vibrio fischeri toxicity in the case of cholinium-based dicationic ILs. Gindri et al. (2014) also found the same tendency for MC3T3-E1 cytotoxicity of imidazolium-based dicationic ILs. Nevertheless, no previous studies have evaluated the Vibrio fischeri toxicity of the dicationic ILs tested in this work.

\subsection{Mono- vs dicationic ILs}

Comparisons of the ecotoxicity of mono- and dicationic ILs were made for the three different cation cores. More specifically, we compared ILs with the same cation core (imidazolium, pyrrolidinium or pyridinium), alkyl chain length (octyl) and anion (bromide): $\mathrm{C}_{8}(\mathrm{MIm}) \mathrm{Br}$ (log 
$\left.\mathrm{EC}_{50}=0.71\right)$ vs $\mathrm{C}_{8}(\mathrm{MIm})_{2} \mathrm{Br}_{2}\left(\log \mathrm{EC}_{50}=2.34\right), \mathrm{C}_{8}(\mathrm{Pyr}) \mathrm{Br}\left(\log \mathrm{EC}_{50}=1.27\right)$ vs $\mathrm{C}_{8}\left(\mathrm{Pyr}_{2} \mathrm{Br}_{2}(\log \right.$ $\left.\mathrm{EC}_{50}=4.52\right)$ and $\mathrm{C}_{8}(\mathrm{MPyrr}) \mathrm{Br}\left(\log \mathrm{EC}_{50}=1.66\right)$ vs $\mathrm{C}_{8}(\mathrm{MPyrr})_{2} \mathrm{Br}_{2}\left(\log \mathrm{EC}_{50}=3.77\right)$. According to the results shown in Tables 1 and 2, the dicationic ILs were less toxic toward the Vibrio fischeri bacterium than their monocationic counterparts. This is in good agreement with the results for cholinium-based ILs obtained by e Silva et al. (2014), who suggested that the reason could be related to the size of the molecules of the ILs, which would restrict their interactions with the cell membranes. Other authors, including Steudte et al. (2014), observed the same trend for mono- and dicationic ILs for their acute toxicity towards IPC-81, S. vacuolatus and D. magna. Recently, Gindri et al. (2014) obtained similar results in a toxicity assay using MC3T3-E1 preosteoblast cells. In this case, the authors affirmed that the reduced toxicity of the ILs may be due to an increase in polarity of the ionic liquid structure.

Monocationic ILs with high alkyl chain lengths show strong attachment of the molecule to the lipid bilayer surface, most likely giving rise to a considerable disruption of the membrane bilayers, consistent with a strong micellization effect. When the alkyl chains in the cationic structure are short and the overall dimension of the molecule is small, the insertion of the compounds into the lipid bilayer is deeper, resulting in lesser membrane-surface perturbation. This explanation was also given by Gal et al. (2012).

In the case of dicationic ILs, the second charge carrier stops the carbon chain, segregating into 310 the membrane structure, hence reduces potency. Until the linker gets long, it then folds like a hairpin and can again segregate into the membrane.

\subsection{Relationship between octanol water partition coefficient $\left(K_{o w}\right)$ and Vibrio fischeri toxicity}

Several authors have claimed that the Vibrio fischeri toxicity of ILs follows the same trend as their hydrophobicity: the more hydrophobic they are, the greater their toxicity (Docherty and Kulpa, Jr., 2005; e Silva et al., 2014; Gindri et al., 2014). One of the parameters to represent the hydrophobicity of a compound is the octanol-water partition coefficient $\left(K_{o w}\right)$ because the water saturated-octanol system closely represents very well the physico-chemical environment of 
living organisms (Montalbán et al., 2015). In a previous study (Montalbán et al., 2016), the authors obtained an empirical correlation between the hydrophobicity (expressed as the Log $\left.K_{o w}\right)$ and the Vibrio fischeri toxicity (expressed as $\log \left(1 / \mathrm{EC}_{50}\right)$ ) based on experimental data of both parameters for a set of twenty-nine ILs:

$$
\log \left(1 / E C_{50}\right)=-1.436+0.859 \log K_{\text {ow }}-0.119\left(\log K_{\text {ow }}\right)^{2}
$$

With the experimental data shown in Tables 1 and 2, we estimated the values of $\log K_{\text {ow }}$ for all the ILs studied in this work using equation (1). The estimated values are shown in Table 3. Apart from by equation (1), two other approaches were used to estimate $K_{o w}$ : the web pages molinspiration.com (“http://www.molinspiration.com/services/logp.html," 2015) and chemicalize.org ("http://www.chemicalize.org/," 2015). These approaches predict the toxicity of a given molecular structure by breaking it up into fragments or groups of atoms which have a previously assigned empirical constant and structural factor. Both approaches use SMILES (Simplified Molecular Input Line Entry System) notation. These estimated values are also depicted in Table 3. 
Table 3. Estimated values of $K_{o w}$ using Equation (1), molinspiration.com ${ }^{a}$ and chemicalize.org ${ }^{b}$ for the studied ILs.

\begin{tabular}{|c|c|c|c|}
\hline IL & $\log K_{o w}($ from Eq 1) & $\log K_{o w}{ }^{a}$ & $\log K_{o w}^{b}$ \\
\hline $\mathrm{C}_{8}(\mathrm{MIm}) \mathrm{Br}$ & $9.78 \mathrm{E}-1$ & -0.02 & -0.37 \\
\hline $\mathrm{C}_{8}(\mathrm{MIm}) \mathrm{NTf}_{2}$ & $6.19 \mathrm{E}-1$ & 2.97 & 2.17 \\
\hline $\mathrm{C}_{8}(\mathrm{MIm}) \mathrm{SbF}_{6}$ & $7.63 \mathrm{E}-1$ & -0.02 & -0.37 \\
\hline $\mathrm{C}_{8}(\mathrm{Pyr}) \mathrm{Br}$ & $1.99 \mathrm{E}-1$ & -1.01 & -0.09 \\
\hline $\mathrm{C}_{8}(\mathrm{Pyr}) \mathrm{NTf}_{2}$ & $-8.51 \mathrm{E}-2$ & 2.97 & 2.17 \\
\hline $\mathrm{C}_{8}$ (Pyr) $\mathrm{SbF}_{6}$ & $3.76 \mathrm{E}-1$ & -1.01 & -0.09 \\
\hline $\mathrm{C}_{8}$ (MPyrr) $\mathrm{Br}$ & $-2.52 \mathrm{E}-1$ & 0.23 & -0.46 \\
\hline $\mathrm{C}_{8}$ (MPyrr) $\mathrm{NTf}_{2}$ & $-1.08 \mathrm{E}-1$ & 2.97 & -0.46 \\
\hline $\mathrm{C}_{8}$ (MPyrr) $\mathrm{SbF}_{6}$ & $5.19 \mathrm{E}-1$ & 0.23 & 2.17 \\
\hline $\mathrm{C}_{2}(\mathrm{MIm})_{2} \mathrm{Br}_{2}$ & -3.17 & -5.45 & -7.11 \\
\hline $\mathrm{C}_{3}(\mathrm{MIm})_{2} \mathrm{Br}_{2}$ & -3.18 & -5.39 & -7.05 \\
\hline $\mathrm{C}_{4}(\mathrm{MIm})_{2} \mathrm{Br}_{2}$ & -2.95 & -5.32 & -6.53 \\
\hline $\mathrm{C}_{6}(\mathrm{MIm})_{2} \mathrm{Br}_{2}$ & -2.66 & -5.00 & -5.64 \\
\hline $\mathrm{C}_{8}(\mathrm{MIm})_{2} \mathrm{Br}_{2}$ & -0.93 & -4.54 & -4.76 \\
\hline $\mathrm{C}_{3}$ (MPyrr) $)_{2} \mathrm{Br}_{2}$ & -2.99 & -5.25 & -7.24 \\
\hline $\mathrm{C}_{4}(\mathrm{MPyrr})_{2} \mathrm{Br}_{2}$ & -2.49 & -5.17 & -6.73 \\
\hline $\mathrm{C}_{6}(\mathrm{MPyrr})_{2} \mathrm{Br}_{2}$ & -2.33 & -4.8 & -5.84 \\
\hline $\mathrm{C}_{8}(\mathrm{MPyrr})_{2} \mathrm{Br}_{2}$ & -2.10 & -4.19 & -4.95 \\
\hline $\mathrm{C}_{2}(\mathrm{Pyr})_{2} \mathrm{Br}_{2}$ & -3.20 & -5.83 & -6.55 \\
\hline $\mathrm{C}_{3}(\mathrm{Pyr})_{2} \mathrm{Br}_{2}$ & -2.66 & -5.79 & -6.49 \\
\hline $\mathrm{C}_{4}(\mathrm{Pyr})_{2} \mathrm{Br}_{2}$ & -2.97 & -5.74 & -5.97 \\
\hline $\mathrm{C}_{6}(\mathrm{Pyr})_{2} \mathrm{Br}_{2}$ & -3.06 & -5.55 & -5.08 \\
\hline $\mathrm{C}_{8}(\mathrm{Pyr})_{2} \mathrm{Br}_{2}$ & -2.63 & -5.31 & -4.19 \\
\hline $\mathrm{C}_{12}(\mathrm{Pyr})_{2} \mathrm{Br}_{2}$ & -0.67 & -4.52 & -2.41 \\
\hline $\mathrm{C}_{3}(\mathrm{Pyr})(\mathrm{MIm}) \mathrm{Br}_{2}$ & -3.09 & -5.61 & -6.77 \\
\hline $\mathrm{C}_{3}$ (Pyr) (MPyrr) $\mathrm{Br}_{2}$ & -2.65 & -5.56 & -6.87 \\
\hline
\end{tabular}

As can be seen in Figure S1 and Table 3, the toxicity of ILs towards Vibrio fischeri increases with increasing $\log K_{o w}$. In addition, it can be observed that for most of the tested ILs, the Log $K_{o w}$ values are negative. It is commonly known that only compounds with $\log K_{o w}$ values between 1 and 5 (Heipieper et al. 1994), i.e. highly hydrophobic, accumulate in bacterial membranes causing modifications of the membrane fluidity and altering the membrane structure and function (Sikkema et al., 1994). Specifically, Log $K_{o w}$ values obtained from Eq. 1 are negative for all the dicationic ILs whereas the values for the monocationic ones are positive or near to zero. The main difference between the cations of the tested dicationic ILs is their different lipophilicity. Heckenbach et al. (2016) reported the influence of hydrophobicity and length of alkyl chain of the cation on ionic liquid toxicity. The lipophilic properties, function of the structure of the ionic liquid, have been correlated with toxicity (Piotrowska et al. 2017; 
Costa et al., 2015; Pham et al., 2010, 2016). This correlation can be explained by accumulation of the compounds in membrane lipid bilayer, that may cause the loss of integrity and ion dysregulation (Sikkema et al., 1995). The higher is Log Kow of the ionic liquid, the higher is its membrane accumulation and toxicity. Therefore, the results of Log $K_{o w}$ also confirm that dicationic ILs are less toxic than their monocationic counterparts although, according to our results, none of them would accumulate in the membrane lipid bilayer.

\section{CONCLUSIONS}

The Vibrio fischeri toxicity, reported as $\log \mathrm{EC}_{50}$, of twenty-six monocationic and dicationic

ILs ranged between 0.71 and 5.37. The experimental values showed very good agreement with those estimated using the QSAR method. Some trends relating the composition and chemical structure of the ILs with their Vibrio fischeri ecotoxicity could be established. According to our results, the strongest influences on the ecotoxicity of the ILs studied are the length of the alkyl chain and the existence of one or two cation cores. The toxicity of ILs increased as a function of alkyl chain length of the substituent of the cation and was mainly related to the cation and not to the nature of the anion. Finally, it was established that the $\mathrm{EC}_{50}$ of dicationic ILs was lower than that observed for the homologous monocationics.

The hydrophobicity of ILs, reported as $K_{\text {ow }}$, was estimated using three approaches and the Log $\left(1 / \mathrm{EC}_{50}\right)$ was seen to be related with $\log K_{o w}$. Because the $\mathrm{EC}_{50}$ values are of the same order as VOCs, we conclude that the aquatic toxicity of these ILs is quite similar to that of industrial VOCs, particularly, dicationic ones. This means that dicationic ILs can be designed for practical and environmentally friendly industrial applications.

\section{ACKNOWLEDGEMENTS}

This work has been partially supported from the European Commission (FEDER/ERDF) and the Spanish MINECO (Ref. CTQ2014-57467-R) and the programme of support to the research of the Seneca Foundation of Science and Technology of Murcia, Spain (Ref. 19499/PI/14). Mercedes G. Montalbán acknowledges support from Spanish MINECO (FPI grant, BES-2012053267 and predoctoral mobility grant, EEBB-I-14-08371). 


\section{REFERENCES}

Anderson, J.L., Ding, R., Ellern, A., Armstrong, D.W., 2005. Structure and properties of high stability geminal dicationic ionic liquids. J. Am. Chem. Soc. 127, 593-604. doi:10.1021/ja046521u

Bechinger, B., 2010. Membrane association and pore formation by alpha-helical peptides. Adv. Exp. Med. Biol. 677, 24-30. doi:10.1007/978-1-4419-6327-7_3

Blundell, R.K., Licence, P., 2014a. Quaternary ammonium and phosphonium based ionic liquids: a comparison of common anions. Phys. Chem. Chem. Phys. 16, 15278-15288. doi:10.1039/c4cp01901f

Blundell, R.K., Licence, P., 2014b. Tuning cation-anion interactions in ionic liquids by changing the conformational flexibility of the cation. Chem. Commun. 50, 12080-12083. doi:10.1039/C4CC05505E

Bruzzone, S., Chiappe, C., Focardi, S.E., Pretti, C., Renzi, M., 2011. Theoretical descriptor for the correlation of aquatic toxicity of ionic liquids by quantitative structure-toxicity relationships. Chem. Eng. J. 175, 17-23. doi:10.1016/j.cej.2011.08.073

Costa, S.P.F., Pinto, P.C.A.G., Saraiva, M.L.M.F.S., Rocha, F.R.P., Santos, J.R.P., Monteiro, R.T.R., 2015. The aquatic impact of ionic liquids on freshwater organisms. Chemosphere 139, 288-294.

Couling, D.J., Bernot, R.J., Docherty, K.M., Dixon, J.K., Maginn, E.J., 2006. Assessing the factors responsible for ionic liquid toxicity to aquatic organisms via quantitative structureproperty relationship modeling. Green Chem. 8, 82-90. doi:10.1039/B511333D

Docherty, K.M., Kulpa, Jr., C.F., 2005. Toxicity and antimicrobial activity of imidazolium and pyridinium ionic liquids. Green Chem. 7, 185-189. doi:10.1039/b419172b

e Silva, F.A., Siopa, F., Figueiredo, B.F.H.T., Gonçalves, A.M.M., Pereira, J.L., Gonçalves, F., 
Coutinho, J.A.P., Afonso, C.A.M., Ventura, S.P.M., 2014. Sustainable design for environment-friendly mono and dicationic cholinium-based ionic liquids. Ecotoxicol. Environ. Saf. 108, 302-310. doi:10.1016/j.ecoenv.2014.07.003

Evans, K.O., 2006. Room-temperature ionic liquid cations act as short-chain surfactants and disintegrate a phospholipid bilayer. Colloids Surfaces A Physicochem. Eng. Asp. 274, 1117. doi:10.1016/j.colsurfa.2005.10.007

Freire, M.G., Carvalho, P.J., Silva, A.M.S., Santos, L.M.N.B.F., Rebelo, L.P.N., Marrucho, I.M., Coutinho, J.A.P., 2009. Ion specific effects on the mutual solubilities of water and hydrophobic ionic liquids. J. Phys. Chem. B 113, 202-211. doi:10.1021/jp8080035

Fuentes, A., Lloréns, M., Sáez, J., Aguilar, M.I., Pérez-Marín, A.B., Ortuño, J.F., Meseguer, V.F., 2006. Ecotoxicity, phytotoxicity and extractability of heavy metals from different stabilised sewage sludges. Environ. Pollut. 143, 355-360. doi:10.1016/j.envpol.2005.11.035

Gal, N., Malferarri, D., Kolusheva, S., Galletti, P., Tagliavini, E., Jelinek, R., Jelinek, R., 2012. Membrane interactions of ionic liquids: Possible determinants for biological activity and toxicity. Biochim. Biophys. Acta - Biomembr. 1818, 2967-2974. doi:10.1016/j.bbamem.2012.07.025

Galinski, M., Lewandowski, A., Stepniak, I., 2006. Ionic liquids as electrolytes. Electrochim. Acta 51, 5567-5580. doi:10.1016/j.electacta.2006.03.016

García, M.T., Gathergood, N., Scammells, P.J., 2005. Biodegradable ionic liquids Part II. Effect of the anion and toxicology. Green Chem. 7, 9-14. doi:10.1039/b411922c

Gindri, I.M., Siddiqui, D.A., Bhardwaj, P., Rodriguez, L.C., Palmer, K.L., Frizzo, C.P., Martins, M.A.P., Rodrigues, D.C., 2014. Dicationic imidazolium-based ionic liquids: a new strategy for non-toxic and antimicrobial materials. RSC Adv. 4, 62594-62602. doi:10.1039/C4RA09906K 
Gouveia, W., Jorge, T.F., Martins, S., Meireles, M., Carolino, M., Cruz, C., Almeida, T.V., Araújo, M.E.M., 2014. Toxicity of ionic liquids prepared from biomaterials. Chemosphere 104, 51-56. doi:10.1016/j.chemosphere.2013.10.055

Han, X., Armstrong, D.W., 2005. Using geminal dicationic ionic liquids as solvents for hightemperature organic reactions. Org. Lett. 7, 4205-4208. doi:10.1021/o1051637w

Heckenbach, M.E., Romero, F.N., Green, M.D., Halden, R.U., 2016. Meta-analysis of ionic liquid literature and toxicology. Chemosphere 150, 266-274. doi: 10.1016/j.chemosphere.2016.02.029

Heipieper, H.J., Weber, F.J., Sikkema, J., Keweloh, H., de Bont, J.A.M., 1994. Mechanisms of resistance of whole cells to toxic organic solvents. Trends Biotechnol. 12, 409-415. doi:10.1016/0167-7799(94)90029-9

445 Hough, W.L., Smiglak, M., Rodríguez, H, Swatloski, R.P., Spear, S.K., Daly, D.T., Pernak, J., Grisel, J.E., Carliss, R.D., Soutullo, M.D., Davis, Jr., J.H., Rogers, R.D., 2007. The third evolution of ionic liquids: active pharmaceutical ingredients. New J. Chem. 31, 1429-1436. doi: 10.1039/b706677p

http://www.chemicalize.org/, 2015.

http://www.molinspiration.com/services/logp.html, 2015.

Ismail Hossain, M., Samir, B.B., El-Harbawi, M., Masri, A.N., Abdul Mutalib, M.I., Hefter, G., Yin, C.-Y., 2011. Development of a novel mathematical model using a group contribution method for prediction of ionic liquid toxicities. Chemosphere 85, 990-994. doi:10.1016/j.chemosphere.2011.06.088

ISO 11348-3. Water quality. Determination of the inhibitory effect of water samples on the light emission of Vibrio fischeri (Luminescent bacteria test). Part 3: Method using freeze-dried bacteria, 2007.

Kaiser, K. LE, Palabrica, V.S., 1991. Photobacterium phosphoreum toxicity data index. Water 
Qual. Res. J. Canada 26, 361-431.

460 Kogelnig, D., Stojanovic, A., Kammer, F.v.d., Terzieff, P., Galanski, M., Jirsa, F., Krachler, R., Hofmann, T., Keppler, B.K., 2010. Tetrachloroferrate containing ionic liquids: Magneticand aggregation behavior. Inorg. Chem. Commun. 13, 1485-1488. doi:10.1016/j.inoche.2010.08.023

Kore, R., Srivastava, R., 2013. A simple, eco-friendly and recyclable bi-functional acidic ionic 465 liquid catalysts for Beckmann rearrangement. J. Mol. Catal. A-Chem. 376, 90-97. doi:10.1016/j.molcata.2013.04.021

Lacrămă, A.-M., Putz, M. V., Ostafe, V., 2007. A Spectral-SAR model for the anionic-cationic interaction in ionic liquids: application to Vibrio fischeri ecotoxicity. Int. J. Mol. Sci. 8, 842-863. doi:10.3390/i8080842

470

Larson, J.H., Frost, P.C., Lamberti, G.A., 2008. Variable toxicity of ionic liquid-forming chemicals to Lemna minor and the influence of dissolved organic matter. Environ. Toxicol. Chem. 27, 676-681. doi:10.1897/06-540.1

Lee, B.-S., Lin, S.-T., 2014. A priori prediction of the octanol-water partition coefficient $\left(\mathrm{K}_{\mathrm{ow}}\right)$ of ionic liquids. Fluid Phase Equilib. 363, 233-238. doi:10.1016/j.fluid.2013.11.042 Technol. Biotechnol. 84, 202-207. doi:10.1002/jctb.2025

Li, X.-Y., Zhou, J., Yu, M., Wang, J.-J., Pei, Y.C., 2009. Toxic effects of 1-methyl-3octylimidazolium bromide on the early embryonic development of the frog Rana nigromaculata. Ecotoxicol. Environ. Saf. 72, 552-556. doi:10.1016/j.ecoenv.2007.11.002 estimate ionic liquids ecotoxicity $\mathrm{EC}_{50}$ (Vibrio fischeri). J. Mol. Liq. 152, 28-33. doi:10.1016/j.molliq.2009.12.008

Luis, P., Ortiz, I., Aldaco, R., Irabien, A., 2007. A novel group contribution method in the 
development of a QSAR for predicting the toxicity (Vibrio fischeri $\mathrm{EC}_{50}$ ) of ionic liquids. Ecotoxicol. Environ. Saf. 67, 423-429. doi:10.1016/j.ecoenv.2006.06.010

Masri, A.N., Abdul Mutalib, M.I., Leveque, J.M., 2016. A Review on Dicationic Ionic Liquids: Classification and Application. Ind. Eng. Manage. 5:197, 1-7. doi:10.4172/21690316.1000197

Matzke, M., Stolte, S., Arning, J., Uebers, U., Filser, J., Greathouse, J.A., Jastorff, B., Ranke, J., Jastorff, B., Schröder, H., Stark, A., Stepnowski, P., Stock, F., Störmann, R., Stolte, S., Welz-Biermann, U., Ziegert, S., Thöming, J., 2008. Imidazolium based ionic liquids in soils: effects of the side chain length on wheat (Triticum aestivum) and cress (Lepidium sativum) as affected by different clays and organic matter. Green Chem. 10, 584-591. doi:10.1039/b717811e

Matzke, M., Stolte, S., Thiele, K., Juffernholz, T., Arning, J., Ranke, J., Welz-Biermann, U., Jastorff, B., 2007. The influence of anion species on the toxicity of 1-alkyl-3methylimidazolium ionic liquids observed in an (eco)toxicological test battery. Green Chem. 9, 1198-1207. doi:10.1039/B705795D

Montalbán, M.G., Collado-González, M., Trigo, R., Díaz Baños, F.G., Víllora, G., 2015. Experimental measurements of octanol-water partition coefficients of ionic liquids. J. Adv. Chem. Eng. 5, 1-9. doi: 10.4172/2090-4568.1000133

Montalbán, M. G., Hidalgo, J. M., Collado-González, M., Díaz Baños, F. G., Víllora, G., 2016. Assessing chemical toxicity of ionic liquids on Vibrio fischeri: Correlation with structure and composition. Chemosphere 155, 405-414. doi: 10.1016/j.chemosphere.2016.04.042 monocationic and dicationic ionic liquids (Submitted to Journal Data in Brief).

Parvez, S., Venkataraman, C., Mukherji, S., 2006. A review on advantages of implementing luminescence inhibition test (Vibrio fischeri) for acute toxicity prediction of chemicals. 
Environ. Int. 32, 265-268. doi:10.1016/j.envint.2005.08.022

510 Pham, T.P.T., Cho, C.-W., Min, J., Yun, Y.-S., 2008. Alkyl-chain length effects of imidazolium and pyridinium ionic liquids on photosynthetic response of Pseudokirchneriella subcapitata. J. Biosci. Bioeng. 105, 425-428.

Pham, T.P.T., Cho, C.-W., Yun, Y.-S., 2010. Environmental fate and toxicity of ionic liquids: A review. Emerg. Contam. water Occur. fate, Remov. Assess. water cycle (from wastewater to Drink. water) 44, 352-372. doi:10.1016/j.watres.2009.09.030

Pham, T.P.T., Cho, C.-W., Yun, Y.-S., 2016. Structural effects of ionic liquids on microalgal growth inhibition and microbial degradation. Environ. Sci. Pollut. Res. 23, 4294-4300. doi: $10.1007 / \mathrm{s} 11356-015-5287-8$

Pinto, P.C.A.G., Costa, S.P.F., Lima, J.L.F.C., Saraiva, M.L.M.F.S., 2012. Automated highthroughput Vibrio fischeri assay for (eco)toxicity screening: Application to ionic liquids. Ecotoxicol. Environ. Saf. 80, 97-102. doi:10.1016/j.ecoenv.2012.02.013

Piotrowska, A., Syguda, A., Wyrwas, B., Chrzanowski, Ł., Heipieper, H.J., 2017. Toxicity evaluation of selected ammonium-based ionic liquid forms with MCPP and dicamba moieties on Pseudomonas putida. Chemosphere 167, 114-119. doi:10.1016/j.chemosphere.2016.09.140

Pretti, C., Chiappe, C., Pieraccini, D., Gregori, M., Abramo, F., Monni, G., Intorre, L., 2006. Acute toxicity of ionic liquids to the zebrafish (Danio rerio). Green Chem. 8, 238-240. doi:10.1039/b511554j

Pretti, C., Renzi, M., Focardi, S.E., Giovani, A., Monni, G., Melai, B., Rajamani, S., Chiappe, 530 C., 2011. Acute toxicity and biodegradability of $N$-alkyl- $N$-methylmorpholinium and $N$ alkyl-DABCO based ionic liquids. Ecotoxicol. Environ. Saf. 74, 748-753.

Romero, A., Santos, A., Tojo, J., Rodríguez, A., 2008. Toxicity and biodegradability of imidazolium ionic liquids. J. Hazard. Mater. 151, 268-273. 
doi:10.1016/j.jhazmat.2007.10.079

535 Samorì, C., Pasteris, A., Galletti, P., Tagliavini, E., 2007. Acute toxicity of oxygenated and nonoxygenated imidazolium-based ionic liquids to Daphnia magna and Vibrio fischeri. Environ. Toxicol. Chem. 26, 2379-2382. doi:10.1897/07-066R2.1

Sikkema, J., de Bont, J.A.M, Poolman, B., 1994. Interactions of cyclic hydrocarbons with biological membranes. J. Biol. Chem. 269, 8022-8028.

540 Sikkema, J., de Bont, J.A.M, Poolman, B., 1995. Mechanisms of membrane toxicity of hydrocarbons, Microbiol. Mol. Biol. Rev. 59, 201-222.

Steudte, S., Bemowsky, S., Mahrova, M., Bottin-Weber, U., Tojo-Suarez, E., Stepnowski, P., Stolte, S., 2014. Toxicity and biodegradability of dicationic ionic liquids. RSC Adv. 4, 5198-5205. doi:10.1039/c3ra45675g

545 Stolte, S., Matzke, M., Arning, J., Böschen, A., Pitner, W.-R., Welz-Biermann, U., Jastorff, B., Ranke, J., 2007. Effects of different head groups and functionalised side chains on the aquatic toxicity of ionic liquids. Green Chem. 9, 1170-1179. doi:10.1039/B711119C

Urbanczyk, H., Ast, J.C., Higgins, M.J., Carson, J., Dunlap, P.V. 2007. Reclassification of Vibrio fischeri, Vibrio logei, Vibrio salmonicida and Vibrio wodanis as Aliivibrio fischeri gen. nov., comb. nov., Aliivibrio logei comb. nov., Aliivibrio salmonicida comb. nov. and Aliivibrio wodanis comb. nov. Int. J. Syst. Evol. Microbiol. 57, 2823-2829. doi:10.1099/ijs.0.65081-0

Ventura, S.P.M., e Silva, F.A., Gonçalves, A.M.M., Pereira, J.L., Gonçalves, F., Coutinho, J.A.P., 2014. Ecotoxicity analysis of cholinium-based ionic liquids to Vibrio fischeri marine bacteria. Ecotoxicol. Environ. Saf. 102, 48-54. doi:10.1016/j.ecoenv.2014.01.003

Ventura, S.P.M., Gardas, R.L., Gonçalves, F., Coutinho, J.A.P., 2011. Ecotoxicological risk profile of ionic liquids: octanol-water distribution coefficients and toxicological data. J. Chem. Technol. Biotechnol. 86, 957-963. doi:10.1002/jctb.2606 
Ventura, S.P.M., Marques, C.S., Rosatella, A.A., Afonso, C.A.M., Gonçalves, F., Coutinho, J.A.P., 2012. Toxicity assessment of various ionic liquid families towards Vibrio fischeri marine bacteria. Spec. Issue Sect. SETAC North Am. 31st Annu. Meet. Adv. Omi. Aquat. Toxicol. 76, 162-168. doi:10.1016/j.ecoenv.2011.10.006

Viboud, S., Papaiconomou, N., Cortesi, A., Chatel, G., Draye, M., Fontvieille, D., 2012. Correlating the structure and composition of ionic liquids with their toxicity on Vibrio fischeri: A systematic study. J. Hazard. Mater. 215-216, 40-48. doi:10.1016/j.jhazmat.2012.02.019

Víllora, G., 2013. Liquid Membranes, Supported and Emulsion. Encyclopedia of Membrane Science and Technology. 1-46. doi: 10.1002/9781118522318.emst103

Viswanathan, G., Murugesan, S., Pushparaj, V., Nalamasu, O., Ajayan, P.M., Linhardt, R.J., 570 2006. Preparation of biopolymer fibers by electrospinning from room temperature ionic liquids. Biomacromolecules 7, 415-418. doi:10.1021/bm050837s

Vraneš, M., Tot, A., Jovanović-Šanta, S., Karaman, M., Dožić, S., Tešanović, K., Kojić, V., Gadžurić, S. 2016. Toxicity reduction of imidazolium-based ionic liquids by the oxygenation of the alkyl substituent. RSC Adv. 6, 96289-96295. doi: 10.1039/c6ra16182k

Wasserscheid, P., Welton, T., 2008. Outlook, in Ionic Liquids in Synthesis, Second Edition, Wiley-VCH Verlag GmbH \& Co. KGaA, 689-704. doi: 10.1002/3527600701.ch9

Wei-Li, D., Bi, J., Sheng-Lian, L., Xu-Biao, L., Xin-Man, T., Chak-Tong, A., 2014. Polymer grafted with asymmetrical dication ionic liquid as efficient and reusable catalysts for the synthesis of cyclic carbonates from $\mathrm{CO} 2$ and expoxides. Catal. Today 233, 92-99. doi:10.1016/j.cattod.2014.02.042

Wells, A.S., Coombe, V.T., 2006. On the freshwater ecotoxicity and biodegradation properties of some common ionic liquids. Org. Process Res. Dev. 10, 794-798. doi:10.1021/op060048i 
Zhang, B., Li, X., Chen, D., Wang, J., 2013. Effects of 1-octyl-3-methylimidazolium bromide 585 on the antioxidant system of Lemna minor. Protoplasma 250, 103-110. doi:10.1007/s00709-012-0379-5

Zhang, Z.X., Zhou, H.Y., Yang, L., Tachibana, K., Kamijima, K., Xu, J., 2008. Asymmetrical dicationic ionic liquids based on both imidazolium and aliphatic ammonium as potential electrolyte additives applied to lithium secondary batteries. Electrochim. Acta 53, 48334838. doi:10.1016/j.electacta.2008.02.008 